\title{
SEJARAH BANJAR TRADISIONAL MENJADI LEMBAGA SOSIAL MASYARAKAT MODEREN DUSUN JURANG KOAK DESA BEBIDAS \\ KECAMATAN WANASABA 2006-2015
}

\author{
Muhammad Shulhan Hadi', Muh. Sawaludin ${ }^{2}$ \\ ${ }^{1,2}$ Universitas Hamzanwadi \\ Muhammadshulhan.hadi@yahoo.com,sawaludin@gmail.com
}

\begin{abstract}
Banjar in the Lombok is home to a collective spirit and ideas Sasak people, the spirit of mutual cooperation is very visible condensed running in the local wisdom ethnic Sasak. A close bond and sturdiness social life and sense of helping each other and need each other naturally born with and develop sponta. Banjar hambpir formed simultaneously with the formation of a shack in the villages in Lombok, when Law No. 5/1974 and Law No. 5/1979 on village administration was enacted, almost all the local knowledge coloring creativity diversity is turned off and terlibas by uniformity / uniformity village concept ala Jakarta, the banjo in Lombok seems lost and no longer function, now in an era of openness banjo as traditional roots ethnic sasak in Lombok is loaded with a spirit of togetherness / collective that emerged and developed back, the emergence banjar in Lombok is not like it used to be. The method used in solving the problem of this research is descriptive qualitative method, respondents, in this this study did not use population but use informants/ study the methods used to collect the data are: Obsrvasi, interviews, Documentation. Based on the analysis in this study can be concluded that the revitalization of Banjar Traditional Being Society of Social Institutions of Modern Hamlet Canyons Koak Village Bebidas District of Wanasaba a creative efforts and systematic and continuing to strengthen the social capital that is in train, so that social energy was great and spontaneous in banjar be managed for productive things. Revitalization of traditional banjo is an answer to the question of socio- cultural people who have faced is poverty.
\end{abstract}

Key Note: Banjar Traditional, Modern Society, Social

\begin{abstract}
Abstrak
Banjar di Lombok merupakan tempat berkembangnya semangat dan gagasan kolektif orang-orang sasak, semangat gotong royong sangat nampak kental berjalan dalam kearifan lokal etnis sasak tersebut. Ikatan erat dan kokoh jiwa sosial dan rasa untuk saling tolong menolong dan saling membutuhkan lahir dengan alami dan berkembang secara sponta. Banjar terbentuk hambpir bersamaan dengan terbentuknya suatu gubuk di desa-desa di Lombok, ketika UU No. 5/1974 dan UU No. 5/1979 tentang pemerintahan desa diberlakukan, hampir seluruh kreatifitas kearifan lokal yang mewarnai kebhinekaan dimatikan dan terlibas oleh uniformitas/keseragaman konsep desa ala Jakarta, maka banjar di Lombok seolah-olah hilang dan tidak berfungsi lagi,
\end{abstract}


kini di era keterbukaan ini banjar sebagai akar tradisional etnis sasak di Lombok yang sarat dengan spirit kebersamaan/kolektif itu muncul dan berkembang kembali, kemunculan banjar di Lombok tidak seperti dululagi. Metode yang digunakan dalam menyelesaikan masalah penelitian ini adalah metode deskriptif kualitatif, penelitian ini tidak menggunakan populasi tapi menggunakan narasumber/responden, dalam penelitian ini metode yang digunakan untuk mengumpulkan data adalah : Obsrvasi, Wawancara, Dokumentasi. Berdasarkan analisis dalam penelitian ini dapat diambil kesimpulan bahwa Revitalisasi Banjar Tradisional Menjadi Lembaga Sosial Masyarakat Moderen Dusun Jurang Koak Desa Bebidas Kecamatan Wanasaba merupakan upaya kreatif dan sistimatis serta berkelanjutan untuk memperkuat modal sosial masyarakat yang ada di dalam banjar, agar energi sosial yang besar dan spontan yang ada di banjar bisa terkelola untuk hal-hal yang produktif. Revitalisasi banjar tradisional ini merupakan jawaban terhadap persoalan sosial kultural masyarakat yang selama ini dihadapi yaitukemiskinan.

Kata Kunci: Banjar Tradisioonal, Masyaeakat Modern.

\section{Latar Belakang}

Pulau Lombok merupakan suatu pulau yang terletak di Provinsi Nusa Tenggara Barat (NTB) Indonesia. Lombok dikenal sebagai daerah yang memiliki beragam kebudayaan menarik sehingga banyak orang-orang yang berasal dari luar daerah atau bahkan yang berasal dari luar negeri sengaja berkunjung ke Lombok untuk menyaksikan langsung bagaimana kebudayaan- kebudayaan masyarakat Lombok. Hal tersebut semestinya bisa menjadi potensi bagi Pulau Lombok atau masyarakat Lombok sebagai aset daerah. Namun, hal tersebut tidak bisa berjalan dengan baik karena banyak faktor kekurangan di Pulau lombok, termasuk kekurangan akses.

Kemiskinan di Lombok jelas karena akses mereka yang terbataas terhadap sumber daya. Sebagai buruh tani dengan lahan garapan yang terus menyusut, sudah pasti hidup petani Lombok jauh dari sejahtera. Kondisi ini semakin runyam dengan tidak terpenuhinya secara layak kebutuhan mendasar dibidang pendidikan dan kesehatan.

Data statistik memperlihatkan dengan terang bagaimana masyarakat pedesaan di Lombok kesulitan mendapatkan akses pendidikan dan kesehatan. Laporan tahunan dinas pendidikan dan olahraga provinsi NTB tahun 2014 disinyalir dari 3667 anak putus sekolah di NTB setiap tahunnya, lebih dari50\% terjadi di Pulau Lombok. Berdasarkan penomena tersebut di Atas, bagaimana potensi modal sosial masyarakat lombok gagal dikelolamenjadisumber daya yang menggerakkan perubahan konstruktif di tengah 
masyarakat. Salah satu modal sosial yang dimiliki masyarakat Lombok adalah institusi lokal bernama “ Banjar" (Bappeda dan BPS2014).

Dalam terminologi masyarakat Lombok, Banjar dipahami sebagai persekutuan komunitas terkecil yang eksistensinya berada pada setiap Gubuk atau Kampung. Dimana di dalam Banjar itu, secara spontan berlangsung kegiatan sosial kemasyarakatan warga sekitar (Farid Tolumundu dan Mohammad Yamin, 2008 : 20).

Sebagai institusi asli masyarakat di gubuk, usia banjar mungkin sama tuanya dengan usia gubuk itu sendiri. Keseluruhan kepala keluarga dalam suatu gubuk secara otomatis menjadi anggota banjar. Secara geneologis, anggota sebuah banjar dalam suatu gubuk biasanya memiliki ikatan darah kekerabatan dari suatu kakek atau nenek buyut yang bersinggungan. Seiring perkembangan zaman dimana proses kawin-mawin lintas gubuk dan desa sering terjadi, cukup banyak juga orang banyak di luar kekerabatan asal yang ikut menetap dalam suatu gubuk ini. Ini memperluas keanggotaan banjar, tidak lagi semata berdasarkan asal-usul geneologis.

Banjar di Lombok tumbuh dan berkembang sejak dahulu kala. Di dalamnya terpatrikan semangat bersiru yang menjadi spirit utama aktifitas banjar. Bersiru adalah bentuk aktif dari kata siru yang bermakna "kesalingan". Semangat bersiru bersifat spontan, kolektif dan berlandaskan rame, yaitu sikap membantu atau menolong sesama dengan sukarela, senang hati dan ikhlas. Prinsip dasar yang menggerakkan bersiru adalahkeyakinanhidup memerlukan interaksi dan berbagi dengan sesama. Banjar terbentuk hampir sama dengan terbentuknya suatu gubuk di desa-desa Lombok. Banjar di Lombok seolah hilang dan tidak berfungsi lagi karena zaman yang telah berubah, kini di era keterbukaan, banjar sebagai akar tradisional etnis sasak di Lombok yang sarat dengan spirit kebersamaan/kolektifitas itu muncul dan berkembang kembali. Kemunculan banjar di Lombok tidak lagi seperti yang dulu. Terdapat fungsi-fungsi lain yang berkembang dalam keberadaan banjar di Lombok serta aktifitas komunal dalam banjarpun semakin kompleks.Hal ini menandakan bahwa banjar di Lombok mengalami sejumlah perubahan dalam fungsi. Banjar di Lombok merupakan tempat berkembangnya semangat dana gagasan kolektif orang-orang sasak. Semangat gotong royong sangat tampak kental berjalan dalam kearifan lokal etnis sasak tersebut. Ikatan erat dan kokoh terbina semenjak gubuk dan banjar terbentuk oleh masyarakatnya. Jiwa 
sosial dan rasa untuk saling tolong menolong dan saling membutuhkan lahir dengan alami dan berkembang secaraspontan.

Fungsi dan aktifitas warga banjar lebih mengarah kepada aktifitas yang berkaitan dengan siklus kehidupan atau daur kehidupan (life cycle).seperti perkawinan dan kematian, fokus kegiatan banjar yang hanya terbatas seperti inilah yang melahirkan terminologi banjar "merariq" (banjar perkawinan) dan banjar "mate" (banjar kematian). Jika dulu masyarakat di Lombok mengenal banjar merarik (banjar perkawinan) dan banjar mate (banjar kematian), maka sekarang di era keterbukaan

sudah mulai terasa, maka aktifitaswargakampungdalambanjarsemakinbertambah.FungsibanjardiLombok tidak hanya terbatas pada penyelesaian permasalahan perkawinan dan kematian anggotanya saja, akan tetapi aktifitas komunal anggota banjar semakin kompleks dan meluas pada bidang pendidikan, kesejahteraan, kesehatan.

Dalam banjar terjadi proses belajar dan pewarisan/inkulturisasi kebudayaan masyarakat. Nilai dan norma kemasyarakatan warga kampung diinternalisasikan kepada setiap orang dan generasinya.Berdasarkan hal-hal tersebut di atas maka peneliti sangat tertarik mengangkat permasalahan Banjar Nurul Iman Jurang Koak terutama dari sudut terbentuknya Banjar sampai dengan dipatenkan menjadi lembaga sosial masyarakat yang moderen dari tahun 2006-2015, sehingga dapat dirumuskan judul pada penelitian ini adalah "Sejarah Banjar Tradisional Menjadi Lembaga Sosial Masyarakat Moderen Dusun Jurang Koak Desa Bebidas Kecamatan Wanasaba 2006-2015

\section{METODE PENELITIAN}

Pendekatan yang digunakan dalam penelitian ini adalah perdekatan kualitatif type deskriptif. Penelitian kualitatif merupakan tradisi tertentu dalam ilmu pengetahuan sosial yang fundamental bergantung dari pengamatan pada manusia baik dalam kawasan maupun dalam. Denzin dan Lincoln mendefinisikan bahwa penelitian kualitatif adalah penelitian yang menggunakan latar ilmiah, dengan maksud menafsirkan fenomena yangterjadi dan dilakukan dengan jalan melibatkan berbagai metode yang ada. (Lexi J. Moleong, 2010 : 39). Adapun metode yang digunakan dalam penelitian ini adalah metode sejarah. Metode sejarah itu sendiri merupakan proses menguji dan 
menganalisa secara kritis rekaman dan peninggalan masa lampau, rekonstruksi yang imajinatif dari pada masa lampau berdasarkan fakta-fakta yang di peroleh dengan menempuh proses itu disebut historiografis. Penelitian yang menggunakan metode sejarah disebut penelitian sejarah yaitu usaha untuk menetapkan fakta dan mencari simpulan yang mengenai hal-hal yang telah lalu yang dilakukan secara sistemtis dan objektif oleh ahli sejarah dalam mencari, mengevaluasi dan menapsirkan bukti-bukti untuk mempelajari masa lalu tersebut.Dalam penelitian sejarah tersebeut tahapantahapan yang terdiri atas heuristic, kritik, interpretasi dan historiografi. (Luis Gottshalk, $1985: 23)$

\section{HASIL DAN PEMBAHASAN}

\section{Latar Belakang Revitalisasi Banjar Nurul Iman Jurang Koak Desa Bebidas Kecamatan Wanasaba}

Banjar Tradisional Dusun Jurang Koak Desa Bebidas Kecamatan Wanasaba Kabupaten Lombok Timur tumbuh dan berkembang sejak dahulu kala. Di dalamnya terpatrikkan semangat besiru yang menjadi spirit utama aktifitas banjar. Besiru adalah bentuk aktif dari kata Siru yang bermakna kesalingan. Semangat besiru bersifat spontan, kolektif dan berlandaskan rame yaitu sikap membantu atau tolong menolong sesama dengan sukarela, senang hati dan ikhlas. Prinsip dasar yang menggerakkan besiru adalah keyakinan hidup memerlukan interaksi dan berbagai dengan sesama.

Semangat besiru inilah yang merupakan modal sosial banjar. Tetapi ia tidak cukup efektif menggerakkan perubahan sebab ia hanya muncul spontan pada momen komunal tertentu saja yaitu saat kematian danperkawinan, di luar dua momen komunal itu, energi sosial masyarakat yang berlimpah itu tidak terpancar.

Fungsi dan aktifitas warga banjar lebih mengarah kepada aktifitas yang berkaitan dengan siklus kehidupan atau daur kehidupan (life cycle).seperti perkawinan dan kematian, fokus kegiatan banjar yang hanya terbatas seperti inilah yang melahirkan terminologi banjar "merariq" (banjar perkawinan) dan banjar "mate" (banjar kematian). Jika dulu masyarakat di Lombok mengenalbanjarmerarik(banjarperkawinan)danbanjarmate(banjarkematian), maka sekarang di era keterbukaan sudah mulai terasa, maka aktifitas warga kampung dalam 
banjar semakin bertambah. Fungsi banjar di Lombok tidak hanya terbatas pada penyelesaian permasalahan perkawinan dan kematian anggotanya saja, akan tetapi aktifitas komunal anggota banjar semakin kompleks dan meluas pada bidang pendidikan, kesejahteraan, kesehatan.

Dalam banjar terjadi proses belajar dan pewarisan/inkulturisasi kebudayaan masyarakat. Nilai dan norma kemasyarakatan warga kampung diinternalisasikan kepada setiap orang dan generasinya. Banjar Nurul Iman merupakan salah satu institusi lokal asli etnis sasak di Dusun Jurang Koak Desa Bebidas Kecamatan Wanasaba Kabupaten Lombok Timur, dimana di dalam banjar tersebut secara spontan berlangsung kegiatan sosial kemasyarakatan warga selingkung, maka usia dari banjar itu hampir sama dengan usia gubuk itu sendiri.

Sebagai salah satu bentuk modal sosial masyarakat yang telah ada sejak dahulu tumbuh dan berkembang di tengah-tengah masyarakat maka, banjar adalah solusi yang sangat baik untuk meningkatkan kesejahteraan masyarakat dengan upaya-upaya pengantasan kemiskinan secara bertahap dengan semangat spiritual yang ada yaitu denga merevitalisasi banjar untuk lebih memperkaya kegiatan-kegiatannya dalam kehidupan masyarakat di banjar.

Kita tahu selama ini kemiskinan di desa lahir dari kebijakan pembangunan yang tidak memberi ruang yang sehat bagitumbuhnyapartisipasi masyarakat dalam mengelola sumber daya yang sebenarnya tersedia untuk mereka. Tertutupnya akses pengelolaan sumber daya melahirkan apa yang disebut dengan kemiskinan struktural, yaitu jenis kemiskikan yang kolektif yang lahir karena kebijakan pembangunan yang salah kaprah.

Arti penting revitalisasi banjar sebagai ikhtiar membangun spirit besiru yang terkelola secara produktif, semakin kuat dengan besarnya realitas kemiskinan masyarakat pedesaan di Desa Bebidas Khususnya Dusun Jurang Koak. Dengan dilakukannya revitalisasi banjar Nurul Iman perubahan-perubahan pola hidup warga masyarakat yang ada dalam banjar semakin bertambah bahkan kegiatan-kegiatan kemasyarakatan di dalam banjar terarah dengan dukungan dan pembinaan yang dilakukan oleh penggagas revitalisasi tersebut seperti Gerakan Masyarakat Sadar Pendidikan

Sebelum terjadinya revitalisasi Banjar Nurul Iman, masyarakat Jurang Koak Desa 
Bebidas Kecamatan Wanasaba mengenal dua jenis banjar yaitu:

a. Banjar Mate atau BanjarKematian

Banjar mate atau banjar kematian merupakan salah satu bentuk solidaritas warga banjar berkumpul dan mengeluarkan secara spontan iuran yang telah disepakati bersama baik berupa uang, beras, kelapa, kayu bakar atau sajian makanan (dulang) bila salah satu kerabat atau warga banjar mendapat musibah kematian (begawe mate).

b. Banjar Merariq atau BanjarPerkawinan

Sebagaimana juga banjar mate atau banjar kematian, banjar merariq atau banjar perkawinan juga persis sama, hanya bedanya pada proses berlangsungnya kegiatan komunal tersebut, kalau banjar mate dilaksanakan ketika ada warga yang mendapat musibah kematian sedangkan banjar merariq dilaksanakan apabila ada warga yang melaksanakan perkawinan (pernikahan). (wawancara dengan Amaq Kurniawati / Nahun, 3 Januari2017).

Selain itu, Banjar Tradisional juga mempunyai ciri-ciri sebagai berikut :

a. Berada di setiap kampung ataugubuk

b. Tidak mengenal manajemen pengelolaantertulis

c. Ketua dipilih secara musyawarah yang biasanya berdasarkan senioritas usia ataukharisma

d. Kegiatan banjar statis, hanya mengurusi prosesi kematiandan perkawinan wargabanjar.

e. Keanggotaan berdasarkan primordialitasgeneologis

f. Iuran anggota insedental danspontan

g. Nyaris tanpa ada pertemuanberkala

h. Tidak memiliki balebanjar

i. Tidak memiliki program berorientasi kedepan

j. Cenderung menjadi organisasi warga yang konsumtif dan pasif. 


\section{Tujuan Revitalisasi Banjar Nurul Iman Menjadi Lembaga Sosial Masyarakat Moderen Dusun Jurang Koak Desa Bebidas Kecamatan Wanasaba}

Melihat fenomena tersebut pada latar belakang keberadaan Banjar Nurul Iman yang begitu historis dan penuh rasa kebersamaan yang tumbuh dan berkembang di tengah masyarakat, sehingga tidak menutup jalan bagi semua pihak yang ingin menumbuhkan dan mengembangkan potensi lokal masyarakat seperti banjar menjadi akses utama untuk memberdayakan masyarakat sehingga banjar tradisional yang hanya sekedar perkumpulan masyarakat yang tidak terorganisir dapat tumbuh dan berkembang menjadi suatu lembaga sosial masyarakat yang lebih maju dan terorganisir. Oleh sebab itu muncullah gagasan dilakukannya revitalisasi banjar oleh masyarakat Jurang Koak Desa Bebidas Kecamatan Wanasaba.

Gagasan revitalisasi banjar penting, revitalisasi banjar bisa dimaknai sebagai upaya kreatif, sistematis dan berkelanjutan untuk memperkuat modal sosial masyarakat yang ada di dalam banjar. Memperkuat disini bisa memberi makna roh atau spirit baru. Bisa juga berarti mengembangkan roh atau spirit yang telah ada. Sederhanaya, gagasan revitalisasi banjar bertujuan menjadikan spirit besiru yang melahirkan energi sosial yang besar dan spontan di banjar, bisa terkelola untuk hal-hal yang produktif.

Gagasan revitalisasi banjar tradisional ini merupakan suatu jawaban terhadap persoalan sosial-kultural masyarakat yang selama ini dihadapi yaitu masalahkemiskinan.Modal sosial masyarakat seperti banjar adalah salah satu potensi yang sangat baik untuk membangun kehidupan masyarakat karna dalam kegiatan banjar itu sudah terjalin ikatan emosional yang sangat kuat antar warga. Oleh sebab itu, dengan adanya pandanganyang lebih maju untuk mengembangkan potensi masyarakat tersebut dan membangun serta meningkatkan kesejahteraan masyarakat kami, maka, gagasan revitalisasi banjar ini sangat cocok dan tepat dilakukan.

Revitalisasi banjar membuktikan bahwa masyarakat lokal pedsaan masih punya harapan besar untuk mendorong perubahan secara mandiri dengan strategi yang tepat dengan pelibatan komunitas warga di banjar sebagai lokomotif perubahan, pelan tapi pasti bisa mem buahkan sesuatu yang menggembirakan. 


\section{Fungsi Banjar Sasak Dalam Kehidupan SosialBudayaWarga Masyarakat Dusun Jurang Koak Desa BebidasKecamatanWanasaba}

Banjar Sasak merupakan tempat berkembangnyasemangatdan gagasankolektiforang-orangsasak.Semangatgotongroyongsangat tampak kental berjalan dalam kearifan lokal etnissasaktersebut.ikatan sosial yang erat dan kokoh terbina semenjak gubuk danbanjarterbentuk olehmasyarakatnya.Jiwasosialdanrasauntuksalingtolongmenolong dansalingmembutuhkanhadirdenganalamidanberkembangsecaraspontan.Fungsidanaktifi tasbanjartradisionaldenganbanjaryangtelahdirevitalisasi berbeda.

Fungsi dan aktifitas warga banjar lebih mengarah kepada aktifitas dengan siklus kehidupan atau daur kehidupan seperti perkawinan dan kematian saja akan tetapi setelah banjar direvitalisasi fungsi dan aktifitas warga banjar semakin bertambah, fungsi dan aktifitas warga banjar tidak hanya terbatas pada penyelesaian masalah perkawinan dan kematian anggotanya saja, akan tetapi aktifitas komunal anggota banjar semakin komplek dan meluas pada bidang pendidikan, kesejahteraan, kesehata.

Bahkan ada lagi pendapat dari warga banjar seperti yang dijelaskan menyatakan :

Setelah banjar direvitalisasi kami merasakan perubahan yang sangat mendalam dalam kehidupan kami sebagai warga banjar, dimana kegiatan banjar kami sebelum direvitalisasi hanya bila ada warga yang mengadakan begawe (pesta) baik itu begawe mate (pesta kematian) atau begawe merariq (pesta perkawinan), sebagai bentuk solidarita warga banjar kami mengeluarkan iuran secara spontan dan tanpa terencana bila ada warga yang melaksanakan salah satu dari pesta tersebut tapi setelah banjar kami direvitalisasi menjadi lembaga yang lebih maju kegiatan banjar kian bertambah tidak hanya mengurus kedua kegiatan tersebut (wawancara dengan Supardi, 12 Januari 2017).

Sebagian lagi dijelaskan oleh Amaq Kurniawati selaku ketua Banjar Nurul Iman menyatakan :Kegiatan banjar setelah direvitalisasi menjadi lebih luas seperti banjar telah mempunyai struktur organisasi yang jelas dengan pembagian divisi-divisi kerja pengurus banjar yang antara lain : pendidikan, ekonomi, pemberdayaan perempuan, kesehatan dan pelestarian lingkungan.

Unutk menopang keberlangsungan kegiatan banjar dilakukan pertemuan rutin bulanan sebagai bentuk silaturrahmi warga banjar untuk saling mendengarkan keluh kesah dan mencari solusi permasalahan yang dihadapi oleh warga banjar setelah 
pertemuan ditutup disini dilakukan pengeluaran rutin warga sebesar Rp. 2.000 (dua ribu rupiah) dengan perincian Rp. 1.000 untuk iuran wajib dan Rp. 1.000 sebagai simpanan warga. Dari iuran wajib yang dikeluarkan oleh warga banjar itulah yang diambil sebagai bantuan untuk membantu warga yang mendapat musibah maupun kesusahan. Bahkan juga banjar dapat menyiapkan pinjaman pendidikan untuk anak warga banjar dengan melakukan urunan dengan warga banjar karena kami sudah merasa sebagai satu keluarga.

Dari sini dapat dilihat dengan jelas, betapa konstitusi lokal itu sangat perlu dikembangkan dalam upaya untuk meningkatkan kesejahteraan maasyarakat, karena lembaga yang sudah tumbuh dan berkembang dimasyarakat sudah terpatri di dalam kehidupan warganya.

\section{Perubahan Pola Hidup Masyarakat Setelah BanjarDirevitalisasi}

Banjar sesungguhnya menjadi sebuahpengikat kebersamaan bagi warga masyarakat, terlebih lagi warga pedesaan yang dibelit berbagai kesulitan, warga masyarakat membentuk kekuatan ekonomi danusaha untuk menunjang kesejahteraan keluarga dan meningkatkan pendidikan anak-anaknya. Jika ada warga anggota banjar yang memiliki Gawean (hajatan), maka warga banjar lainnya sudah berdatangan dengan sendirinya tanpa harus diminta atau diundang. Nilai-nilai kebersamaan yang dianut bersama oleh setiap anggota banjar menjadi pengikat integritas anggotanya.

Perubahan pola hidup masyarakat warga banjar setelah dilakukannya revitalisasi banjar tradisional ini jauh berubah, aktifitas banjar yang mulanya berkumpul hanya pada acara perkawinan atau kematian saja kini telah berubah. Dengan adanya urunan/iuran sukarela setiap bulannya maka banjar dapat membantu warganya utuk melakukan pendidikan warganya bahkan untuk biaya berobat warganya, sehingga manfaat yang didapat dalam banjar sangatlah besar sekali.

Semangat gotong royong dan saling menolong sesama warga banjar telah membangun semangat yang kuat warga banjar untuk membangun kehidupan warganya dengan kehidupan yang lebih baik bahkan tali silaturrahim warga banjar kian terpatri.

Kesadaran warga banjar akan pentingnya pendidikan bagi anak-anaknya telah membangunkan mereka dari tidur yang panjang, karena selama ini warga banjar tidak 
pernah memperhatikan pendidikan bagi anak-anak mereka karena himpitan ekonomi, karena mata pencarian warga Banjar Nurul Iman $70 \%$ buruh tani, $10 \%$ petani, $20 \%$ tukang bangunan, dengan adanya revitalisasi banjar ini dampaknya sangat baik sekali bagi warga Banjar Nurul Iman baik dibidang ekonomi dan pendidikan karena kesemuanya itu terajut dalam kebersamaan saling mendukung antara warga yang satu dengan yang lainnya. Disamping itu, dengan adanya pertemuan rutin setiap bulnannyasemakinmembangunrasasilaturrahimyangkianeratsesama warga karena kegiatan pertemuan ini tidak dilakukan secara spontanitas akan tetapi terjadwal setiap bulannya.

Dengan adanya kegiatan rutin, warga banjar menjadi geger dan segala sesuatu yang akan dibutuhkan di kegiatan selanjutnya senantiasa disiapkan lebih awal tidak perlu terburu-buru mencari ketika hari dibutuhkan sepertisebelumnya.

Setelah banjar direvitalisasi, kita jadi lebih mudah mendapatkan/memperoleh kebutuhan yang kadang-kadang datang dengan tiba-tiba khususnya bagi pedagang seperti saya. Misalnya saja pengusaha kecil-kecilan seperti saya yang berjualan baju keliling, saya kan sistim jualannya memberikan pelanggan berhutang tanpa saya batasi waktunya, kadang-kadang banyak pelanggan yang lama sekali membayar hutangnya, dengan begitu otomatis modal saya kan tidak bisa balik dan dengan begitu saya tidak bisa lagi mengambil barang dagangan di stok yang biasa saya mengambil barang. Dengan adanya koperasi simpan pinjam di balai banjar, saya agak merasa ringan karena kapan saja kebutuhan tiba-tiba datang bisa saja saya atasi dengan meminjam uang di koperasi banjar dengan syarat-syarat tertentu.

\section{Fungsi Banjar Sasak Dalam Kehidupan Sosial Budaya Warga Masyarakat Dusun Jurang Koak Desa Bebidas KecamatanWanasaba}

Banjar merupakan bentuk persekutuan etnis sasak yang dipergunakan sebagai wadah untuk saling tolong menolong dalam berbagai aktifitas budaya sehari-hari. Selain itu, banjar juga bisa dipanadang sebagai bentuk lembaga kemasyarakatan pada tingkat lokal yaitu lembaga yang terdapat pada tiap kampung di Lombok. Sebagai sebuah persekutuan hidup masyarakat di kampung, di dalam banjar terdapat hal-hal yang menarik yang membuat setiap anggotanya secara spontan dan bersama-sama 
membangun solidaritas sosial dan kebersamaan. Masalah yang dihadapi oleh seorang anggota misalnya menjadi masalah semua anggota banjar lainnya.

Fungsi dan aktifitas warga banjar lebih mengarah pada aktifitas yang berkaitan dengan siklus kehidupan atau daur kehidupan, seperti kematian dan perkawinan. Fokus kegiatan banjar yang hanya terbatas seperti inilah yang melahirkan terminologi banjar merariq (banjar perkawinan) dan banjar mate (banjar kematian).jika dulu masyarakat Jurang Koak Desa Bebidas hanya mengenal banjar Merarik dan banjar Mate, maka fungsi dan aktifitas warga dalam banjar semakin bertambah. Fungsi banjar tidakhanyaterbatas pada penyelesaian masalah perkawinan dan kematian anggotanya saja, akan tetapi aktifitas komunal anggota banjar semakin komplek.

Kini Banjar Nurul Iman telah berubah menjadi suatu lembaga sosial kemasyarakatan yang moderen yang mempunyai struktur organisasi yang terbagi dalam empat divisi yaitu : Pendidikan, Kesehatan, Pemberdayaan Ekonomi, Pemberdayaan Perempuan. Masing-masing divisi ini akan bertanggung jawab terhadap pengembangan dan kemajuan pelayanan terhadap warga banjar sehingga perubahan yang diharapkan benar-benar terjadi setelah banjar direvitalisasi. Dengan demikian aktifitas dan fungsi banjar kian bertambah tidak hanya mengurus measalah perkawinan dan kematian saja akan tetapi Banjar Nurul Iman juga memperhatikan kesejahteraan warganya.

\section{Perubahan Pola Hidup Masyarakat Dusun Jurang Koak Setelah Banjaar Direvitalisasi Dibandingkan Sebelum Banjar Nurul Iman Direvitalisasi}

Banjar di Lombok sesungguhnya menjadi sebuah pengikat kebersamaan bagi warga masyarakat, terlebih lagi bagi warga pedesaan yang dibelit berbagai kesusahan dan kesulitan. Warga masyarakat membentuk kekuatan ekonomi dan usaha menunjang kesejahteraan keluarga dan meningkatkan pendidikananak-anaknya.

Kita bisa membayangkan betapa terbelakangnya kehidupan masyarakat di Dusun Jurang Koak Desa Bebidas Kecamatan Wanasaba, karena dari segi geografis Dusun Jurang Koak berbatasan langsung denganTaman Nasional Gunung Rinjani, yang lahan pertaniannya adalah lahan tanah hujan dan kurang produktif sehingga dimusim kemarau lahan-lahan warga ini banyak yang tidak digunakan, sebagai masyarakat yang ada di pinggiran hutan salah satu mata pencaharian yang dilakukan oleh warga Dusun Jurang 
Koak Desa Bebidas adalah dengan melakukan perambahan hutan (ilegal loging) untuk memenuhi kebutuhan mereka.bahkan mereka tidak pernah memikirkan keberlangsungan pendidikan anak-anak mereka, namun kini setelah institusi lokal mereka yaitu banjar direvitalisasi, banjar sebagai sarana yang sangat efektif untuk melakukan perubahan-perubahan pola hidup yang ada dalam masyarakat, banjar mempunyai peranan yang sangat besar untuk memberikan perubahan, salah satu kegiatan yang dilakukan oleh banjar untuk warganya yaitu dengan memberikan pelatihan- pelatihan keterampilan seperti pertukangan, usaha ekonomi produktif, dan membuka Pendidikan Anak Usia Dini (PAUD).

Betapa besar peranan banjar sebagai suatu lembaga sosial dengan fungsinya menjaga dan mempertahankan nilai-nilai yang sangat tinggi dalam kehidupan masyarakatnya, namun juga berkaitan erat dengan pencapaian berbagai kebutuhan manusia. Banjar Nurul Iman sangat berperan dalam merubah taraf hidup masyarakat Dusun Jurang Koak Desa Bebidas Kecamatan Wanasaba baik dari segi pendidikan, kesehatan, ekonomi, sosial budaya masyarakat, bahkan Banjar Nurul Iman telah mampu membuka kesadaran warganya akan pentingnya arti pendidikan bagianak-anak.

\section{KESIMPULAN}

Sesuai dengan hasil penelitian dan pembahasan, maka dapat disimpulkan sebagai berikut:

1. Banjar Nurul Iman Jurang Koak Desa Bebidas Kecamatan Wanasaba pada umumnya adalah sama seperti banjar-banjar yang ada di desa-desa lain di Lombok ini, namun seiring dengan perkembangan zaman dan kesadaran masyarakatnya, Banjar Nurul Iman direvitalisasi menjadi Lembaga Sosial Masyarakat Moderen dengan tujuan untuk meningkatkan taraf hidup masyarakat Jurang Koak Desa Bebidas baik di bidang Pendidikan, Ekonomi maupunKesehatan.

2. Sebelum Banjar Nurul Iman direvitalisasi, Pola hidup masyarakat Jurang Koak Desa Bebidas masih belum mengenal tentang pentingnya pendidikan bagi anak-anak mereka, perekonomian tidak tentu, dan kesehatanpun kurang diperhatikan dikarenakan kurangnya akses bahkan tidak ada. Stelah Banjar 
Nurul Iman Jurang Koak direvitalisasi pola hidup masyarakat Jurang Koak Desa Bebidas mulai berubah, dilihat dari pendidikan anak-anak sudah mulai diperhatikan seperti di selenggarakannya PAUD (Pendidikan Anak Usia Dini) yang dilaksanakan setiap pagi hari di Balai Banjar Nurul Iman Jurang Koak, dilihat juga dari segi ekonomi, di Balai Banjar Nurul Iman Jurang Koak terdapat koperasi simpan pinjam uang yang dimana koperasi tersebut khusus untuk warga.

\section{DAFTAR PUSTAKA}

Arikunto. Suharsismi. 2002. Prosedur Penelitian Suatu Pendekatan Praktik. Jakarta . Rineka Cipta

Bintarto. 1989. Interaksi Desa Kota dan Permasalahannya. Ghalia Indonesia Jakarta

Dedi Mulyana. 2001. Metodologi Penelitian Kualitatif. Remaja Rosdakrya. Bandung

Departemen Pendidikan dan Kebudayaan. 1997. Adat Istiadat Daerah Nusa Tenggara Barat. CV Eka Darma. Jakarta.

Elizabeth. Metode Etnografi. Yogyakarta. Tiara Wacana Yogya

Burhan Bungin. 2009. Penelitian Kualitatif, Komunikasi. Ilmu dan Sosial Lainnya. Jakarta : Kencana Pernada Media Grup

Koentjaraningrat. 2009. Pengantar Ilmu Antropologi. Jakarta. Rineka Cipta

Lexi J. 2010. Moleong Metodologi Penelitian Kualitatif. Bandung : Remaja Rosdakarya Luis Gottshalk. 1985. Mengerti Sejarah. Jakarta : Universitas Indonesia.

Sadikin Ali. 2004. Buku Ajar Sejarah Lokal. Sekolah Tinggi Keguruan dan Ilmu Pendidikan (STKIP) Hamzanwadi Selong. Jurusan Ips. Program Studi Pendidikan Sejarah

Sudirman. 2008 Gumi Sasak Dalam Sejarah. Selong : Yayasan Budaya Sasak Lestari Sugiyono. 2013. Metode Penelitian Kuantitati., kualitatif dan R\&D. Bandung : Alfabeta. Suharsimi Arikunto. 2006. Prosedur Penelitian. Jakarta : Rineka Cipta,2006.

Spradley. James P. 1977 The Etnographic Interview. a.b. MisbahZulfa

Tolumundu. Farid dan Yamin. Moh. Besiru . Revitalisasi Banjar di Lombok. 